\title{
Fracture Toughness of Veneering Ceramics for Fused to Metal (PFM) and Zirconia Dental Restorative Materials
}

\begin{tabular}{|c|c|}
\hline Volume 115 & Number 5 \\
\hline $\begin{array}{l}\text { Janet B. Quinn, George D. } \\
\text { Quinn, }\end{array}$ & $\begin{array}{l}\text { Veneering ceramics designed to be } \\
\text { used with modern zirconia framework } \\
\text { restorations have been reported to }\end{array}$ \\
\hline American Dental Association & fracture occasionally in vivo. The \\
\hline Foundation, & fracture toughness of such veneering \\
\hline Paffenberger Research Center, & ceramics was measured and compared \\
\hline National Institute of Standards & $\begin{array}{l}\text { to that of conventional feldspathic } \\
\text { porcelain veneering ceramics for }\end{array}$ \\
\hline and Technology, & metal framework restorations. The \\
\hline Gaithersburg, MD & $\begin{array}{l}\text { fracture toughness of the leucite free } \\
\text { veneer was measured to be }\end{array}$ \\
\hline and & $\begin{array}{l}0.73 \mathrm{MPa} \mathrm{m} \pm 0.02 \mathrm{MPa} \mathrm{m} \text {, which } \\
\text { is less than that for the porcelain }\end{array}$ \\
\hline Veeraraghaven Sundar & $\begin{array}{l}\text { fused to metal }(\mathrm{PFM}) \text { veneering } \\
\text { ceramic: } 1.10 \mathrm{MPa} \pm 0.2 \mathrm{MPa} \text {. }\end{array}$ \\
\hline Dentsply Prosthetics, & (Uncertainties are one standard \\
\hline 550 West College Av & deviation unless otherwise noted.) \\
\hline York, PA & The surface crack in flexure (SCF) \\
\hline ҮOК, ГА & $\begin{array}{l}\text { method was suitable for both } \\
\text { materials, but precrack identification }\end{array}$ \\
\hline & was difficult for the leucite containing \\
\hline VeeraraghavenSundar@dentsply. & feldspathic porcelain PFM veneer. \\
\hline
\end{tabular}

September-October 2010

\section{Janet B. Quinn, George D.} Quinn

American Dental Association Foundation,

Paffenberger Research Center, National Institute of Standards and Technology,

and

\section{Veeraraghaven Sundar \\ Dentsply Prosthetics, 550 West College Avenue, george.quinn@nist.gov}

\author{
Veneering ceramics designed to be \\ restorations have been reported to \\ to that of conventional feldspathic \\ fracture toughness of the leucite fre \\ r was measured to be \\ Pa $m \pm 0.02 \mathrm{MPa}$, which \\ fused to metal (PFM) veneering \\ Uncertainties are one standard \\ deviation unless otherwise noted.) \\ surface crack in flexure (SCF) \\ materials, but precrack identification \\ was difficult for the leucite contain
}

Available online: http://www.nist.gov/jres

Key words: dental restorations; fracture toughness; hardness; PFM; surface crack in flexure; veneering ceramic; zirconia.

Accepted: September 10, 2008

\section{Introduction}

Over the last 15 years, zirconia has seen use as a substructure material for the fabrication of fixed prosthodontic restorations, i.e., crowns and bridges. Zirconia is regarded as offering superior strength, toughness and reliability over other ceramic materials due to the transformation toughening mechanisms of its microstructure [1-3]. Clinical studies are now available that support zirconia's performance potential, with indications of expanded functionality compared with other ceramics, such as use in long span bridges [4-8]. The primary issues noted in such studies were not related to framework integrity, but rather chipping, wear, and fracture of the veneering ceramic $[9,10]$. A recent study suggests that such chipping could also be an issue around endodontic access openings for all-ceramic crowns [11].
These observations prompted thinking about differences between porcelain fused to metal (PFM) veneering ceramics, which have been used for over 40 years [12], and the more recently developed veneering ceramics intended for zirconia. The veneers exhibit some compositional and microstructural differences, but are manufactured to identical international standards in terms of mechanical properties [13]. Veneer compositions are adjusted so that their thermal expansions are optimized for the framework materials they are designed to be used with. Hence, PFM veneers are different than those for zirconia. Based on clinical observations, as well as the in-vitro materials data, the question arises whether zirconia veneering ceramics are more susceptible to chipping than PFM veneering ceramics. 
In a companion paper, the fracture resistance of the respective veneers were measured by their edge chip resistance [14]. Bilayer PFM and PFZ (porcelain fused to zirconia) test coupons were subjected to edge loading by a sharp conical indenter near the edge. Resistance to fracture was assessed by measuring the force necessary to flake a chip off the side of the test coupon. Surprisingly, there was very little difference in edge chip resistance between the PFM and PFZ veneers.

To further examine potential differences in the fracture resistance of the respective veneers, the fracture toughness, $\mathrm{K}_{\mathrm{Ic}}$, of each type of veneer was measured using the surface crack in flexure (SCF) method. In this method, which is schematically illustrated in Figs. 1-3, a Knoop indentation is positioned in the center of each flexure test bar at sufficient load to cause cracks to form. Crack orientation may be controlled by orienting the Knoop indentation axis. After indentation, 4.5 to 5 times the depth of the indent is removed from the surface of each bar. This is an important step, for it eliminates the residual stresses resulting from the indentation, and leaves a stress-free semielliptical crack in the bar surface. The bars are then

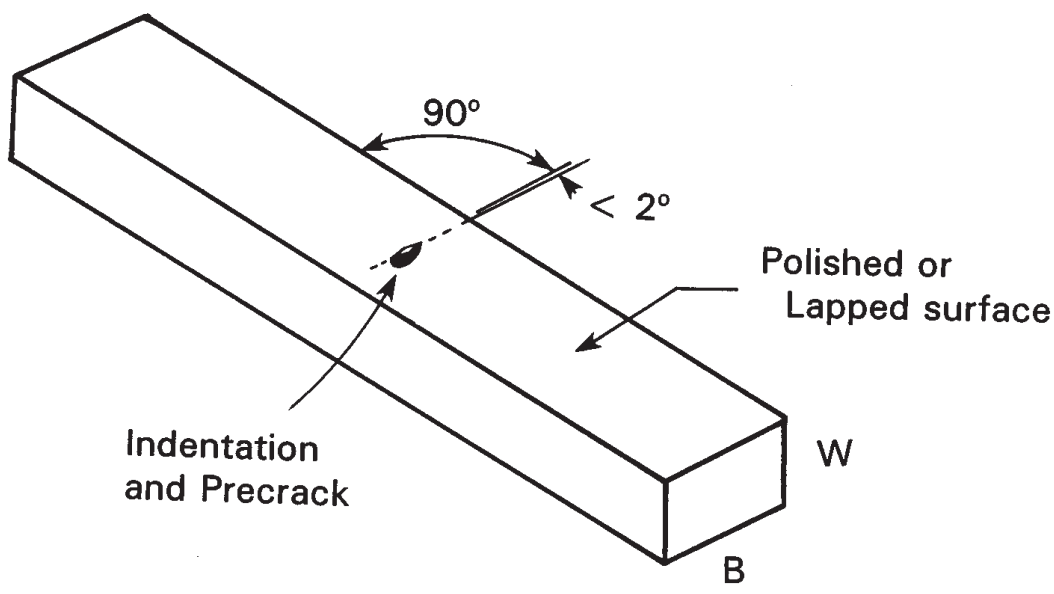

Fig. 1. The surface crack in flexure (SCF) method. An aligned Knoop indentation is used to create a semielliptical precrack on a bend bar.

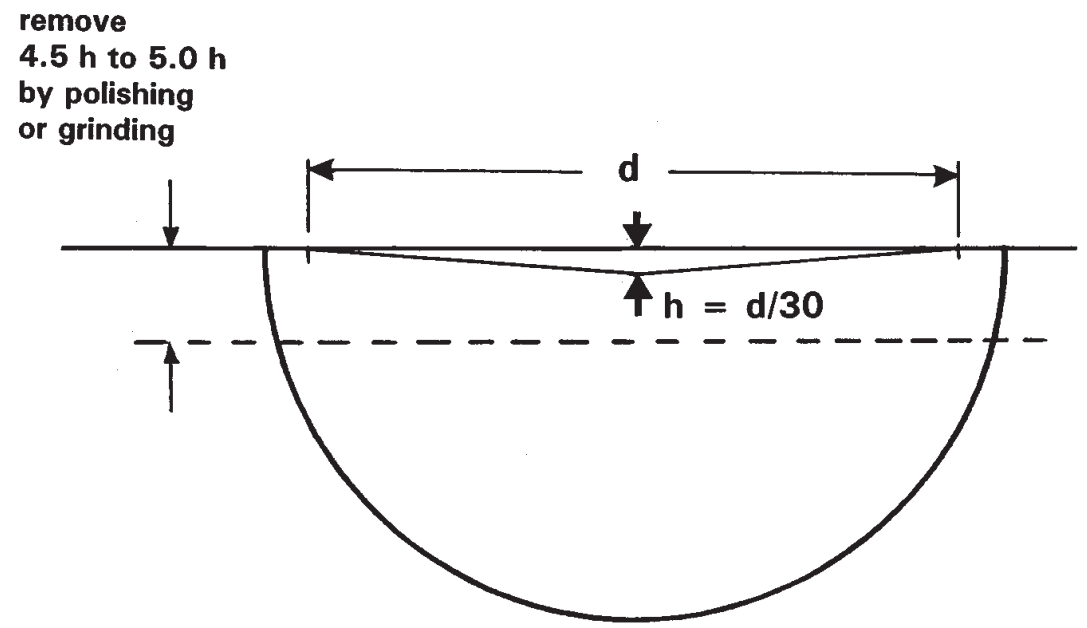

Fig. 2. Schematic of the indentation that is $d$ long and $h$ deep and the precrack that pops in underneath it. Between $4.5 \mathrm{~h}$ and $5.0 \mathrm{~h}$ must be removed to eliminate the indentation damage zone and its associated residual stresses. 


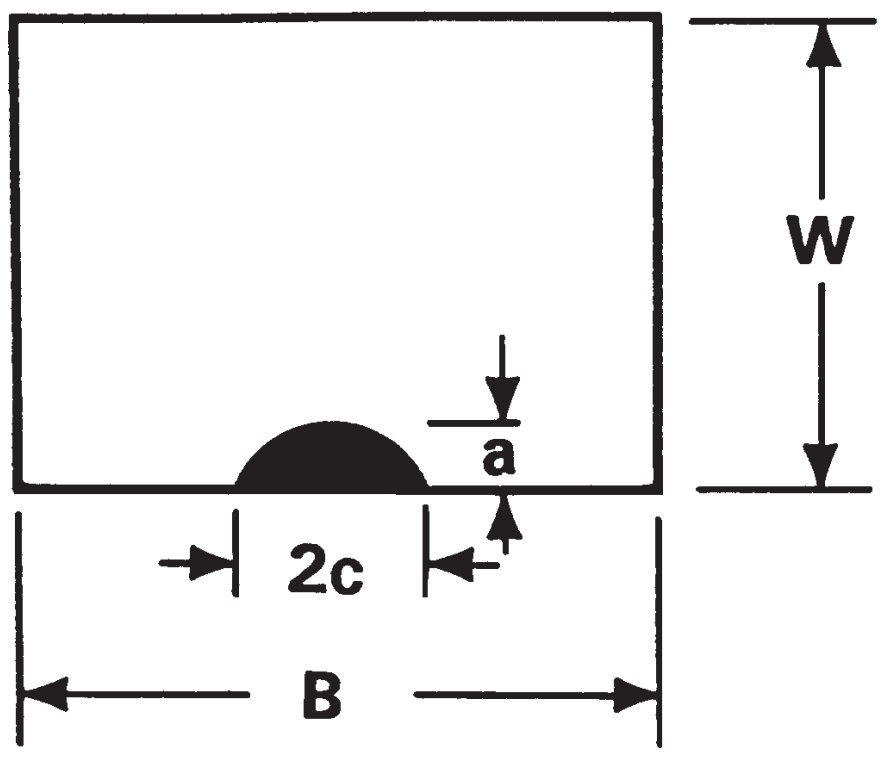

Fig. 3. Schematic of the beam cross section with a semielliptical surface crack. The precrack size is exaggerated in this view for clarity.

tested in flexure and break at the semi-elliptical crack if it is large enough. The size of the crack is measured on the fracture surface of each specimen, and substituted into formulae for calculating $\mathrm{K}_{\mathrm{Ic}}$, along with the specimen size and break stress. One advantage of the SCF method is that it gives a fracture toughness result germane to small cracks, of the order of size of the naturally occurring flaws in a brittle material. This method has been used previously for dental restoration ceramics [15] and has been standardized by ASTM Int. $[16,17]$, the International Organization for Standardization (ISO) [18], and the European Committee for Standards (CEN) [19]. It was the focus of a major Versailles Advanced Materials and Standards (VAMAS) international round robin [20-22]. It also was one of the core methods used to prepare Standard Reference Material (SRM) 2100, the world's only reference material for the property fracture toughness, $\mathrm{K}_{\mathrm{Ic}},[23,24]$. SCF results were identical to within $0.01 \mathrm{MPa} \sqrt{ } \mathrm{m}$ to those from chevron notch in bending and single-edge precracked beam experiments. In other words, the three methods produced virtually identical results on the reference material, which has a very fine grain size and had a flat R-curve (such that fracture toughness was independent of the crack size). Although the method has been widely used to measure fracture toughness of a wide range of ceramics (e.g., [25]), it does have limitations. The SCF method will not work on all ceramic materials. The following criteria must be met:

1. The material must be hard and brittle.

2. It must be possible to detect the precracks on the fracture surface after fracture.

3. The precrack size should be larger than the natural flaws in the material.

Difficulties arise if the material is coarse-grained, porous, too tough, or too soft. It is difficult to detect the precracks if the material is coarse grained or porous. Also, if the material is porous or soft, cracks will not form under the indentation. If the material has too great a fracture toughness, then only small precracks form and they may be removed when the indentation damage zone is removed in the polishing step.

The goals of this work were to ascertain whether the SCF method was suitable for dental veneering ceramics and whether a conventional PFM veneer had a different resistance to fracture than a new PFZ veneer. 


\section{Materials and Methods}

\subsection{Materials}

A vacuum dental furnace (model: Centurion VPC, Dentsply Prosthetics, York, PA) was used to fire six $2.8 \mathrm{~mm} \times 3.6 \mathrm{~mm} \times 42 \mathrm{~mm}$ long beam specimens in rectangular molds. The PFM veneer was Ceramco 3 (Dentsply Prosthetics, York, PA) ${ }^{1}$, a feldspathic veneering porcelain containing about 0.30 volume fraction leucite. The veneer for the zirconia, Ceramco PFZ (Dentsply Prosthetics, York, PA), was designed to be used with a 3 mole $\%$ yttria stabilized zirconia (Cercon) made by the same manufacturer. This veneer is a feldspathic porcelain with negligible leucite. The Ceramco 3 veneer for the alloy had a heat up rate of $55^{\circ} \mathrm{C} / \mathrm{min}$ to a peak firing temperature of $960^{\circ} \mathrm{C}$ and 0 min hold. The Ceramco PFZ veneer for the zirconia had a heat up rate of $60{ }^{\circ} \mathrm{C} / \mathrm{min}$ to a peak temperature of $900{ }^{\circ} \mathrm{C}$ and a short $15 \mathrm{~s}$ hold on the first firing and $890^{\circ} \mathrm{C}$ and 0 min hold on the second firing. The specimens were rough-polished on the four long surfaces to eliminate any bowing or small surface lumps. The two $3.6 \mathrm{~mm}$ wide surfaces were more carefully polished with successively smaller grits down to 1200 grit. A companion paper has additional information including edge chip resistance and Knoop hardness measurements for both veneering ceramics [14].

\subsection{Methods: SCF Fracture Toughness}

Knoop indentations with a load of $39.2 \mathrm{~N}$ (4 kg mass on the indenter) were placed on one of the wide $3.6 \mathrm{~mm}$ surfaces. The indentation and the residual stresscreating damage zone associated with the indentation were removed to a depth of 4.5 to 5.0 times the depth of the indentation, h, by hand grinding with 180 grit silicon carbide abrasive papers. The Knoop indentation lengths, $\mathrm{d}$, were of the order of $370 \mu \mathrm{m}$ for the zirconia veneer so that the indentation depths $(\approx 1 / 30$ th of the diagonal length) were about $12 \mu \mathrm{m}$ deep. Thus, about $60 \mu \mathrm{m}$ of material was removed by the hand grinding. Lateral cracks around the indentation were detected for the PFZ veneer, but they were removed by the grinding. The indentations were about $440 \mu \mathrm{m}$ long for the PFM veneer, so about $73 \mu \mathrm{m}$ was removed by hand grinding for each bar.

\footnotetext{
${ }^{1}$ Commercial products and equipment are identified only to specify adequately experimental procedures and does not imply endorsement by the authors, institutions or organizations supporting this work, nor does it imply that they are necessarily the best for the purpose.
}

Fractographic techniques are used to detect and measure the precrack on the fracture surface after test specimen fracture [26]. The precrack size was measured for each test specimen. The precracks were very easy to detect on the zirconia veneer. A stereoptical microscope (Leica MZ16, Wetzlar, Germany) with a traversing stage with a resolution of $1 \mu \mathrm{m}$ was used to measure the precrack width, $2 \mathrm{c}$, and depth, a, on the fracture surfaces. The precacks were far more difficult to measure in the PFM veneer since the fracture surface was much rougher. One half of each specimen was coated with a thin sputter applied gold coating (such as is done for scanning electron microscope examination) in order to facilitate viewing with the stereoptical microscope. The coating cut down on internal light scattering in this translucent material and improved contrast.

Bars were broken in three-point flexure with a $20 \mathrm{~mm}$ span, taking care that the precrack was well centered under the middle loading roller. The $42 \mathrm{~mm}$ long bars could have been tested in four-point loading with $20 \mathrm{~mm}$ and $40 \mathrm{~mm}$ fixture spans, but the shorter span fixture was used so that two breaks could be obtained with some of the test pieces. Four-point loading is usually recommended for the SCF method [16-21, 23-25], to ensure that the precrack is within a constant stress region, obviating the need for meticulous alignment in three-point testing. All testing was done in laboratory ambient conditions at a crosshead rate of $0.5 \mathrm{~mm} / \mathrm{min}$.

Fracture toughness $\left(\mathrm{K}_{\mathrm{Ic}}\right)$ was calculated from the formula for a semicircular or semielliptical surface crack in tension or flexure:

$$
\mathrm{K}_{\mathrm{Ic}}=\mathrm{Y} \sigma \sqrt{\mathrm{a}}
$$

where $\mathrm{Y}$ is the stress intensity shape factor, $\sigma$ is the flexure strength of the specimen (MPa), and a is the crack depth (m). Y is dimensionless and is a function of the crack size and shape and was individually calculated for each precrack. The solutions by Newman and Raju [27] were used. The maximum $\mathrm{Y}$ value from around the crack front periphery was used to compute $\mathrm{K}_{\mathrm{Ic}}$. For the precracks in this study, this was often where the precrack intersected the tensile surface, but usually the $\mathrm{Y}$ values varied by less than $10 \%$ around the precrack periphery. One surprise about the SCF method is that computed fracture toughness values are not especially sensitive to the measurement of the precrack size. This is due in part to the square root dependence of $\mathrm{K}_{\mathrm{Ic}}$ on the crack size, but also due to an offsetting influence of $\mathrm{Y}$ on the crack size measurement. For 
example, as discussed in Scherrer et al., [15], multiple observers using different photos and measurements obtained $\mathrm{K}_{\mathrm{Ic}}$ values that agreed on average to within $0.01 \mathrm{MPa} \sqrt{ } \mathrm{m}$ for a dental feldspathic porcelain. Additional details about $\mathrm{Y}$ and the SCF method may be found in [15-21, 25].

\section{Results}

Precracks were very difficult to measure in the veneering ceramic for the PFM. Figure 4 shows some examples. The precracks were interpreted both from the photos and from direct viewing in the stereoptical microscope which gives a much clearer threedimensional view. Our difficulty in interpreting precrack sizes with this material was similar to our previous experiences with another feldspathic porcelain [15]. In the latter study, scanning electron microscope examination was a very helpful adjunct to the optical examinations, but it was not necessary in this study. Only five of the six specimens produced measureable precracks. The precracks had depths that ranged from $141 \mu \mathrm{m}$ to $226 \mu \mathrm{m}$, with an average of $162 \mu \mathrm{m}$.

(a)

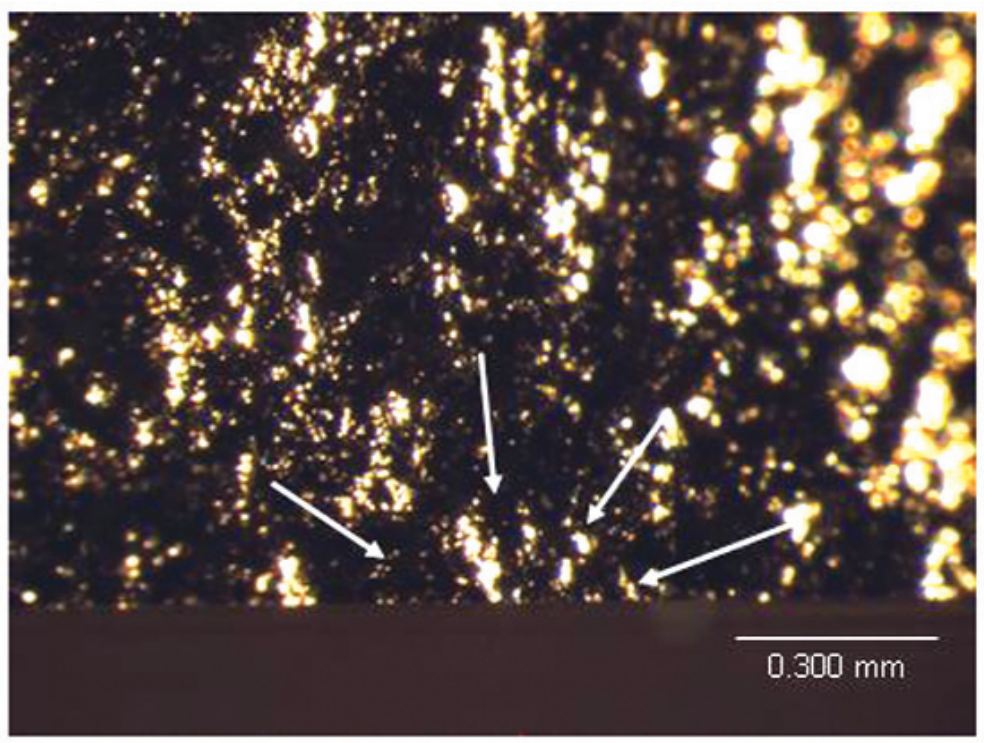

(b)

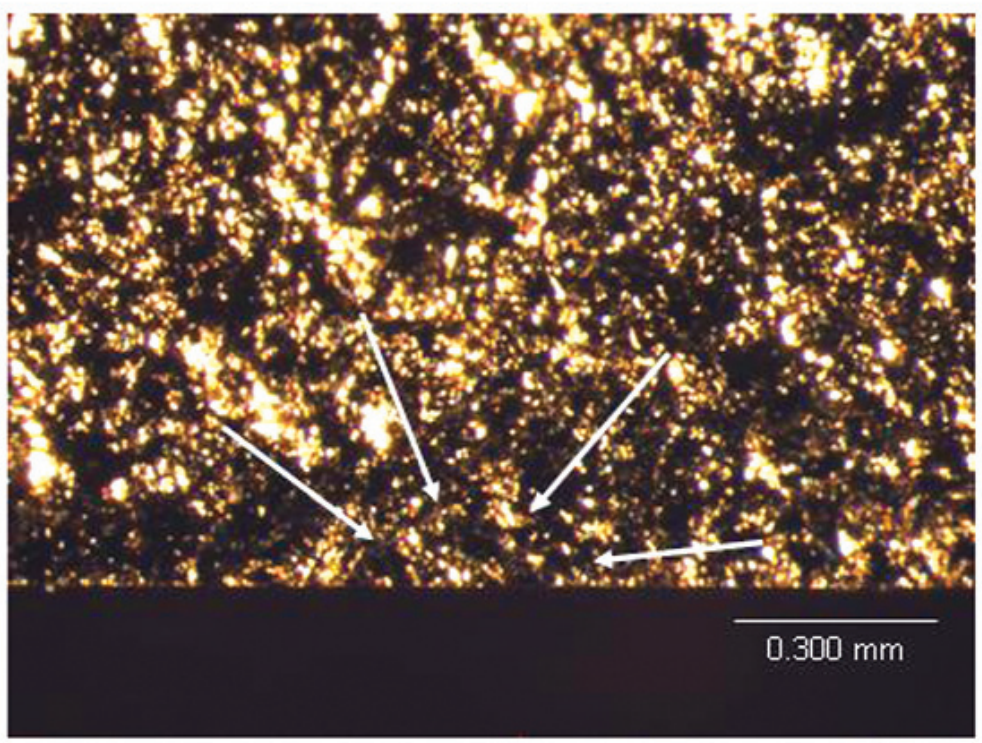

Fig. 4. Examples of Precracks in the veneer for the PFM system (a), (b), and (c, continued on next page). 
(c)

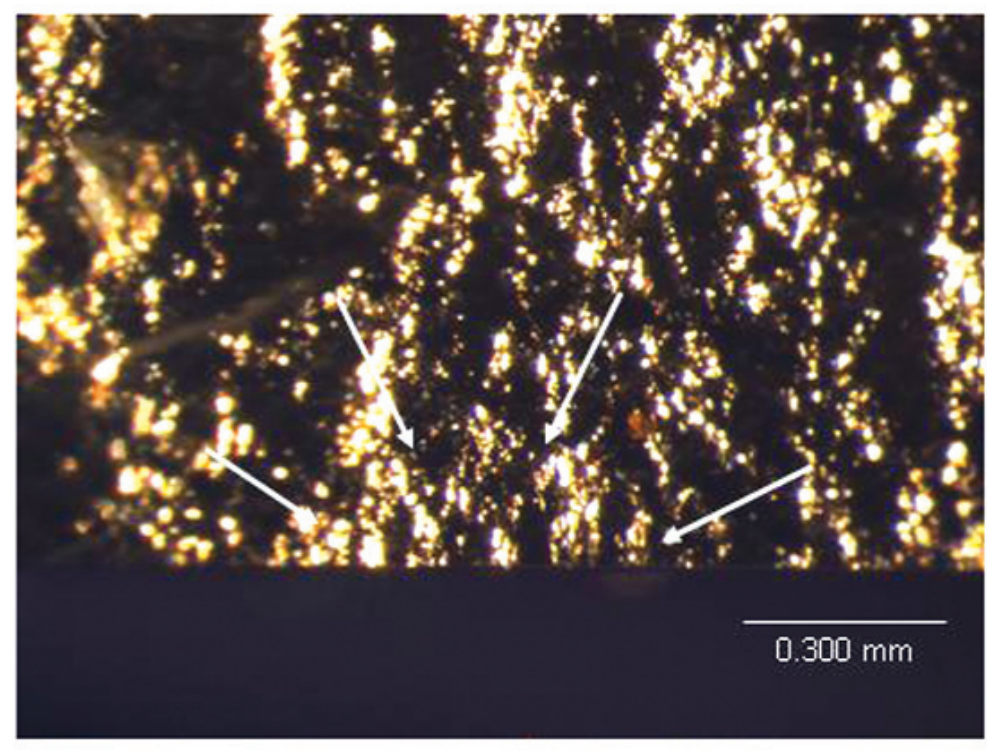

Fig. 4. Examples of Precracks in the veneer for the PFM system ( (c) continued ).

The precrack widths ranged from $339 \mu \mathrm{m}$ to $534 \mu \mathrm{m}$ with an average of $417 \mu \mathrm{m}$. Flexural strengths for the beam ranged from $61 \mathrm{MPa}$ to $77 \mathrm{MPa}$. The fracture toughness was $1.10 \mathrm{MPa} \sqrt{ } \pm 0.13 \mathrm{MPa} \sqrt{ }$. (Uncertainties are one standard deviation unless otherwise noted.)

In contrast, the semi-elliptical cracks in the Ceramco PFZ were very easy to measure. From the six specimens, five good breaks from the precracks were obtained as shown in Fig. 5, which shows the range of sizes and appearances. A large bubble caused fracture in another trial, and grinding scratches caused breakage in two other tests. The dark-light variations are optical effects from variable reflections of the precrack and the surrounding material. Several precracks showed concentric bands, suggesting that the precrack popped-in in multiple steps or that the precrack grew stably during the final fracture test. The largest outer crack was used for the fracture toughness calculations. The precracks ranged in size from depths of $157 \mu \mathrm{m}$ to $221 \mu \mathrm{m}$, with an average of $192 \mu \mathrm{m}$. The precrack widths ranged from $403 \mu \mathrm{m}$ to $505 \mu \mathrm{m}$ with an average of $443 \mu \mathrm{m}$. Flexural strengths ranged from $39 \mathrm{MPa}$ to $45 \mathrm{MPa}$. The average fracture toughness was $0.73 \mathrm{MPa} \sqrt{ } \mathrm{m}$ with a standard deviation of only $0.02 \mathrm{MPa} \sqrt{ }$.

\section{Discussion}

The fracture toughness of the PFM veneer $(1.10 \mathrm{MPa} \sqrt{ } \pm 0.13 \mathrm{MPa} \sqrt{ } \mathrm{m})$ is statistically significantly greater $(50 \%)$ than that for the PFZ veneer (0.73 MPa $\sqrt{ } \mathrm{m} \pm 0.02 \mathrm{MPa} \sqrt{ } \mathrm{m}, \mathrm{P}<0.01 \%$, Students' t distribution). This is not surprising since the PFM veneer that has leucite reinforcing crystals that improve fracture toughness. The leucite is also used to create thermal expansion compatibility with metal substructures. Our fracture toughness results are comparable to those previously measured by us using the single-edged V-notched beam method $(0.99 \mathrm{MPa} \sqrt{\mathrm{m}} \pm 0.06 \mathrm{MPa} \sqrt{ } \mathrm{m}$ to $1.26 \mathrm{MPa} \sqrt{ } \mathrm{m} \pm 0.04 \mathrm{MPa} \sqrt{ } \mathrm{m}$ ) for similar feldspathic PFM porcelains [28]. Our result is also comparable to SCF results by Scherrer et al., [15]. In the latter study, specimens tested in an inert environment (dry nitrogen gas) had a fracture toughness of $1.02 \mathrm{MPa} \sqrt{\mathrm{m}} \pm$ $0.01 \mathrm{MPa} \sqrt{ } \mathrm{m}$ which was $0.09 \mathrm{MPa} \sqrt{ } \mathrm{m}$ greater on average than results for experiments done under lab ambient conditions $(0.93 \mathrm{MPa} \sqrt{\mathrm{m}} \pm 0.06 \mathrm{MPa} \sqrt{ } \mathrm{m})$. The reduced fracture toughness was due to slow crack growth from water vapor in the air.

Leucite is not needed for thermal expansion purposes in the PFZ veneering ceramic since the thermal 
Volume 115, Number 5, September-October 2010

Journal of Research of the National Institute of Standards and Technology

(a)

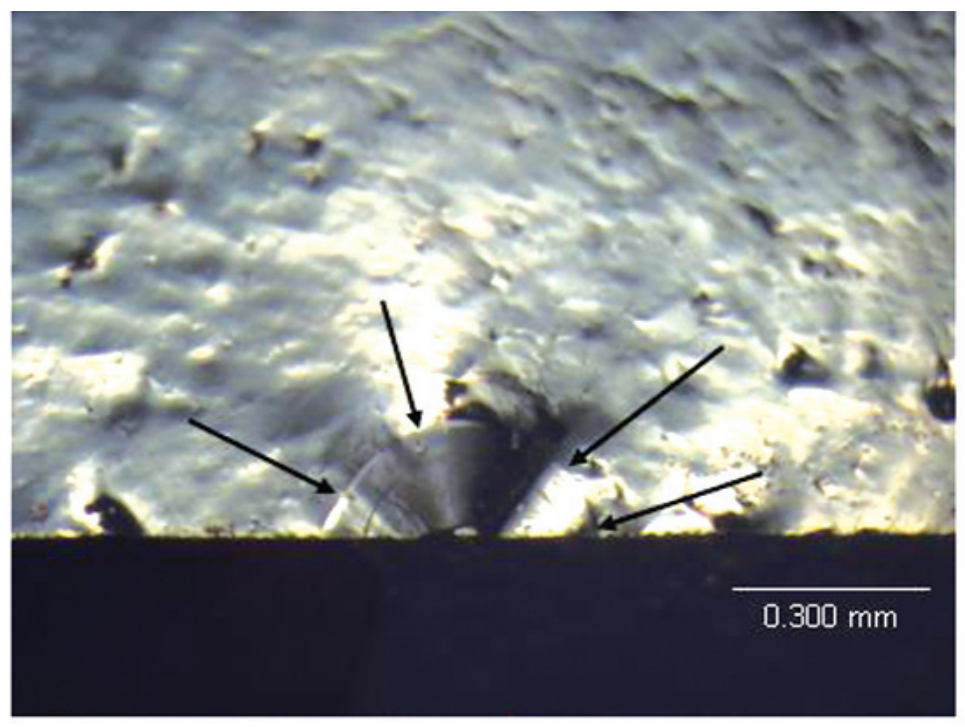

(b)

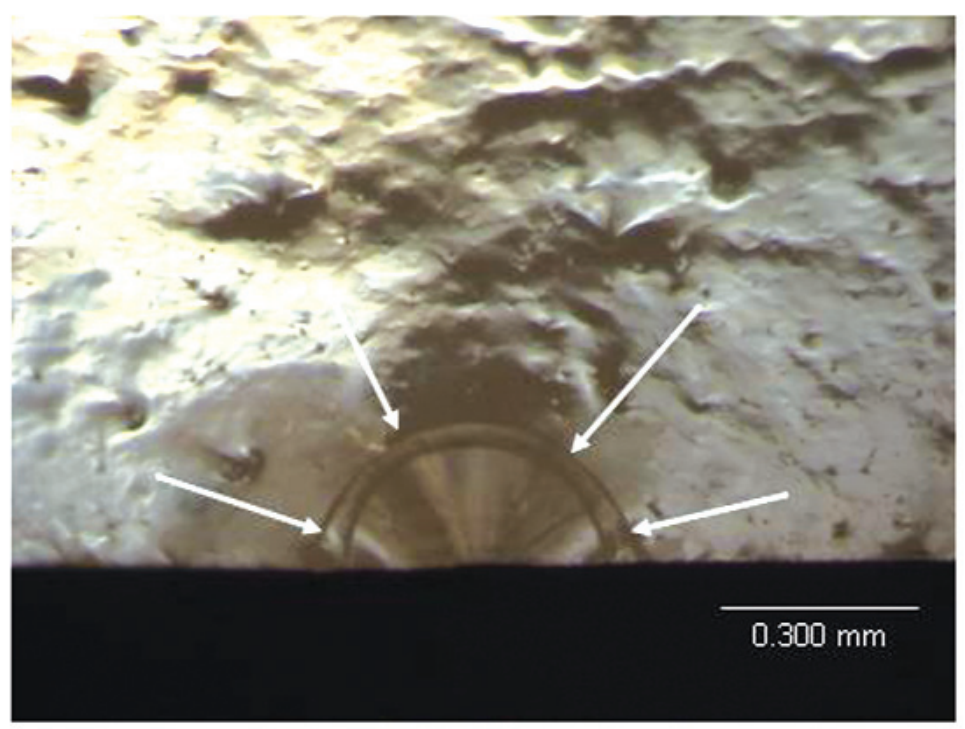

(c)

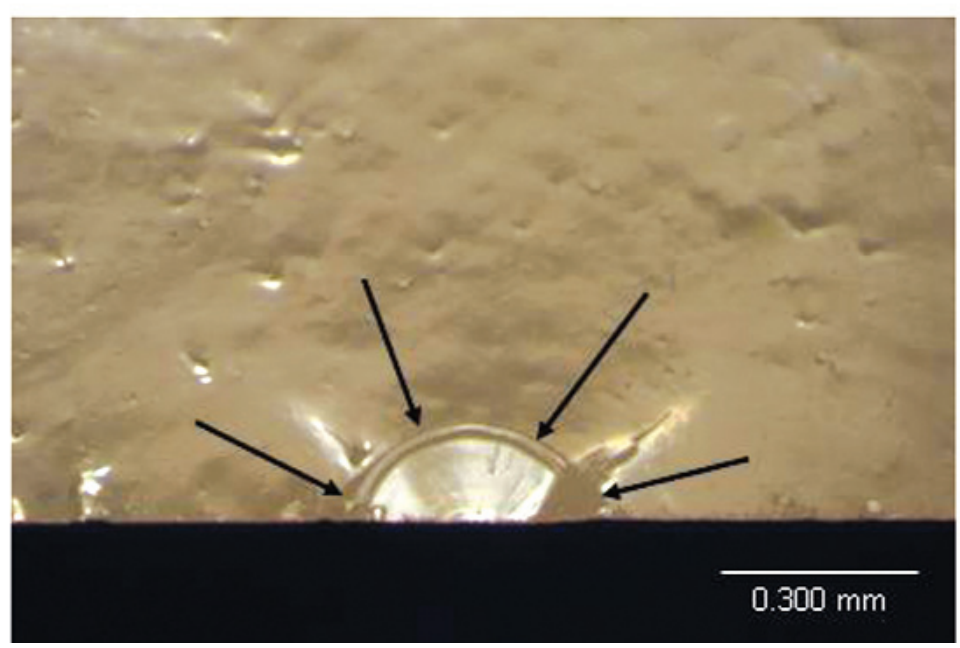

Fig. 5. Precracks in the veneer for the PFZ system (a), (b), (c), and ((d) and (e), continued on next page). 

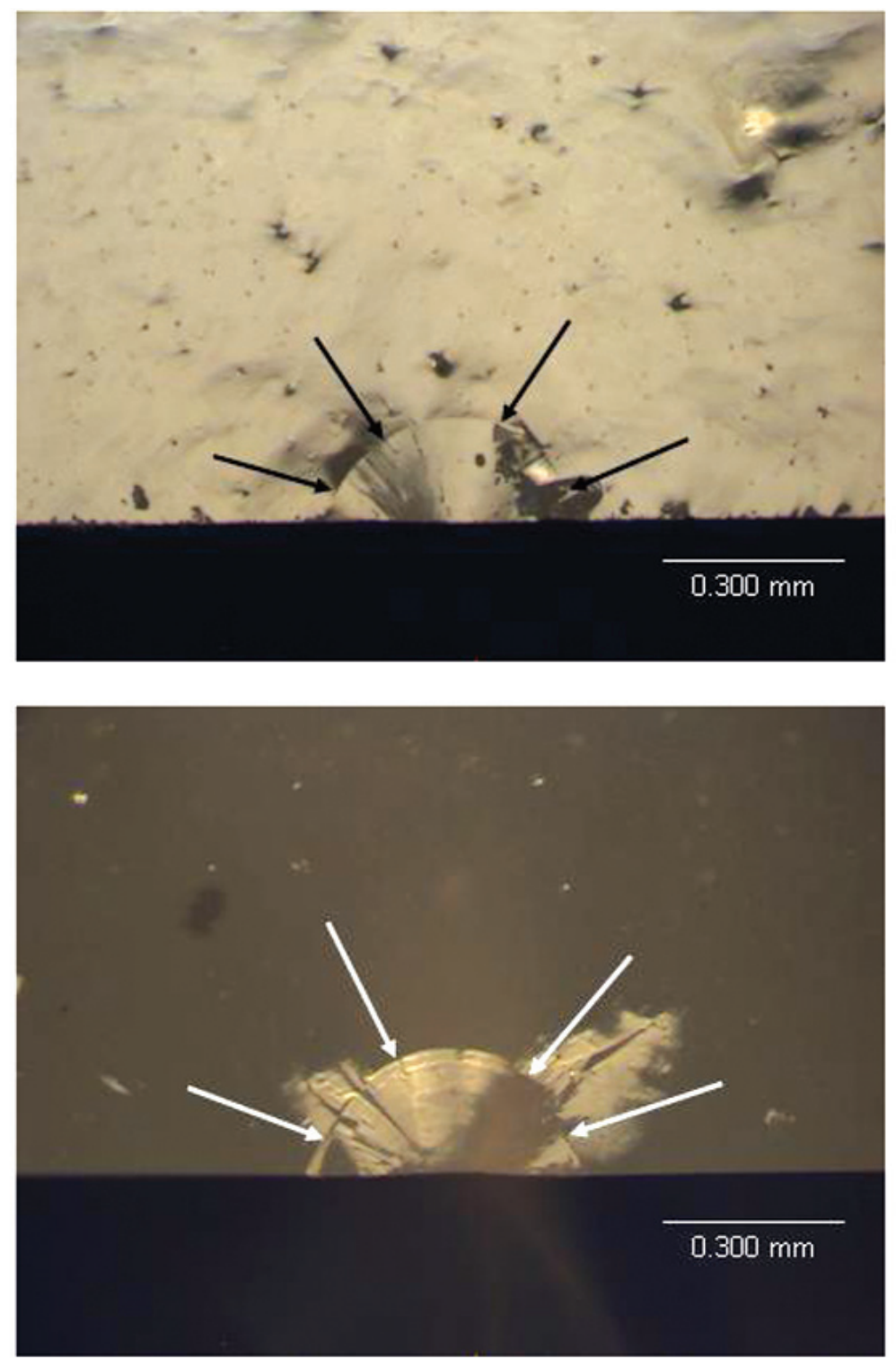

Fig. 5. Precracks in the veneer for the PFZ system ( (d) and (e) continued).

expansion of zirconia is much less than of dental noble metals. The PFZ veneer is a multiphase mixture of glass compositions. Accordingly, the fracture surfaces of the PFZ veneer were very flat and glassy in appearance. Indeed, the fracture toughness is comparable to but slightly less than values for common soda lime glasses $(0.75 \mathrm{MPa} \sqrt{ } \mathrm{m}$ to $0.80 \mathrm{MPa} \sqrt{ } \mathrm{m})$, possibly since slow crack growth may have occurred in our experiments that were conducted in laboratory ambient conditions.
These results are in contrast with previous findings [14] that showed the fracture resistance of both veneers were very similar. The earlier study used the edge chipping procedure to measure the resistance to chip fracture with a sharp indenter under load near a well defined edge of a test piece. The load $\left(\mathrm{F}_{\mathrm{c}}\right)$ necessary to cause a chip at a given distance $\left(d_{e}\right)$ from the edge varied with the square of the distance in accordance with:

$$
\mathrm{F}_{\mathrm{c}}=\mathrm{Ad}_{\mathrm{e}}{ }^{2}
$$


where A was a proportionality constant. A was $407 \mathrm{~N} / \mathrm{mm}^{2}$ for the zirconia veneer and $440 \mathrm{~N} / \mathrm{mm}^{2}$ for the PFM veneer, an $8 \%$ difference. Although some studies have shown that edge toughness scales with fracture toughness, our new results suggest fracture toughness and edge toughness are two different indices of resistance to fracture.

The SCF fracture toughness technique was successful in these instances, but interpretation of the precracks was very difficult in the case of the veneer for the PFM system. A simple dye penetration procedure to highlight the precracks would be a welcome step to facilitate interpretation, but past efforts have had mixed successes. Dyes are effective in some materials, but ineffective in others due to variations in wetabilty and the tightness of the rather small Knoop precracks. Although we were able to obtain valid fractures in three-point loading, four-point is much preferred and should be used in the future due to the strong stress gradients in the former. Future testing of such oxide ceramics should be done in inert environmental conditions to minimize possible interferences from slow crack growth.

The reduced fracture toughness of the veneering ceramic for the zirconia system could be an important factor in the difference in the clinical behavior. It has also been reported recently that residual stresses in the zirconia veneering ceramic may also contribute to their increased propensity to fracture $[29,30]$.

\section{Conclusion}

The fracture toughness of the leucite containing feldspathic porcelain veneering ceramic intended for use with PFMs was $1.10 \mathrm{MPa} \sqrt{\mathrm{m}} \pm 0.13 \mathrm{MPa} \sqrt{\mathrm{m}}$. It is greater than that for a veneering ceramic designed for zirconia: $0.73 \mathrm{MPa} \sqrt{ } \mathrm{mm} \pm 0.02 \mathrm{MPa} \sqrt{\mathrm{m}}$. The SCF method was suitable for both materials, but precrack identification was difficult for the leucite containing feldspathic porcelain PFM veneering ceramic.

\section{Acknowledgements}

This work was supported by National Institute for Standards and Technology, American Dental Association Foundation and National Institute of Health with grant NIH R01-DE17983.

\section{References}

[1] E. C. Subbarao, Zirconia: an overview, in Advances in Ceramics, vol. 3. Science and Technology of Zirconia, eds. A. H. Heuer, L. W. Hobbs (Elsevier, Amsterdam) (1981).

[2] C. Piconi and G. Maccauro, Zirconia as a ceramic biomaterial, Biomater. 20, 1-25 (1999).

[3] J. Tinschert, D. Zwez, R. Marx, and K. J. Anusavice, Structural reliability of alumina-, feldspar-, leucite-, mica- and zirconiabased ceramics, J. Dent. 28 [7], 529-35 (2000).

[4] F. Beuer, H. Aggstaller, T. Fishcher, K. Spiegl, J. Schweiger, and W. Gernet, Clinical behavior of zirconia based bridges: Two-years results, J. Dent. Res. 86, (Spec Iss A), Abst. No. 0901 (2007).

[5] S. Wolfart, S. Eschbach, and M. Kern, Outcome of posterior FPDs of veneered zirconia ceramic (Cercon), J. Dent. Res. 86 (Spec Iss A), Abst. No. 0292 (2007).

[6] P. Vult Von Steyern, P. Carlson, and K. Nilner, All-ceramic fixed partial dentures designed according to the DC-Zirkon ${ }^{\circledR}$ technique: A 2-year clinical study, J. Oral Rehab. 32 [3], 180187 (2005).

[7] J. Tinschert, G. Natt, P. Latzke, K. A. Schulze, N. Heussen, and H. Spiekermann, 5-Jahres-Ergebnisse-Bewährung von voll-keramischen Brücken aus DC-Zirkon ${ }^{\circledR}$, Deutsche Zahnartzeblatt 1 [16], 116-19 (2007).

[8] F. P. Nothdurft, P. R. Rountree, and P. R. Pospiech. Clinical long-term behavior of zirconia-based bridges (LAVA): Five years results, J. Dent. Res. 85 (Spec Iss C), Abst. No. 0312 (2006).

[9] I. Sailer, H. Lüthy, A. Feher, M. Schumacher, P. Schärer, and C. Hämmerle, 3-year results of zirconia posterior fixed partial dentures made by Direct Ceramic Machining (DCM), J. Dent. Res. 82 (Spec Iss B), Abst. No. 0074 (2003).

[10] R. Hickel, Trends in materials science from the point of view of a practicing dentist, J. Eur. Cer. Soc. 29, 1283-1289 (2009).

[11] K. C. Wood, D. W. Berzins, Q. Luo, G. A. Thompson, J. M. Toth, and W. W. Nagy, Resistance to fracture of two allceramic crown materials following endodontic access, J. Prosthet. Dent. 95 [1], 33-41 (2006).

[12] K. F. Leinfelder, Porcelain esthetics for the 21st century, J. Am. Dent. Assoc. 131 [1], 47S-51S (2000).

[13] ISO 6872. Dentistry-Ceramic Materials, International Organization for Standardization, Geneva, SW (2008).

[14] J. B. Quinn, V. Sundar, E. E. Parry, and G. D. Quinn, Comparison of Edge Chipping Resistance of PFM and Veneered Zirconia Specimens, Dental Materials. 26 [1], 13-20 (2010).

[15] S. Scherrer, J. R. Kelly, G. D. Quinn, and K. Xu. Fracture Toughness $\left(\mathrm{K}_{\mathrm{Ic}}\right)$ of a Dental Porcelain Determined by Fractographic Analysis, Dental Materials. 15 [5], 342-348 (1999).

[16] ASTM C 1421-99, Standard Test Method for Determination of Fracture Toughness of Advanced Ceramics at Ambient Temperature. Annual Book of Standards, Vol. 15.01, ASTM, West Conshohocken, PA, (1999).

[17] J. A. Salem, G. D. Quinn, M. G. Jenkins, Measuring the Real Fracture Toughness of Ceramics-ASTM C 1421, pp. 531- 554 in Fracture Mechanics of Ceramics, Vol. 14, R. C. Bradt, D. Munz, M. Sakai, and K. W. White, eds., 2005, Springer, USA, (2005). 
[18] ISO 18756, Fine Ceramics (Advanced Ceramics, Advanced Technical Ceramics) - Determination of Fracture Toughness of Monolithic Ceramics at Room Temperature by the Surface Crack in Flexure (SCF) Method, ISO Geneva, 2003.

[19] EN 14425, European Standard, Advanced Technical Ceramics Monolithic Ceramics-Fracture Toughness-Parts 1-5, European Committee for Standardization, Brussels, 2003.

[20] G. D. Quinn, R. J. Gettings, and J. J. Kübler, Fracture Toughness of Ceramics by the Surface Crack in Flexure (SCF) Method: Results of the VAMAS Round Robin, Ceramic Engineering and Science Proceedings, 15 [5], 846-855 (1994).

[21] G. D. Quinn, J. J. Kübler, and R. J. Gettings, Fracture Toughness of Advanced Ceramics by the Surface Crack in Flexure (SCF) Method: A VAMAS Round Robin, VAMAS Technical Report \#17, National Institute of Standards and Technology, Gaithersburg, MD 20899, (1994).

[22] G. D. Quinn, The Fracture Toughness Round Robins in VAMAS: What We Have Learned, pp. 107-126 in Fracture Resistance Testing of Monolithic and Composite Brittle Materials, ASTM STP 1409, J. A. Salem, G. D. Quinn, M. G. Jenkins, eds., (ASTM, West Conshohocken, PA) (2002).

[23] SRM 2100, Fracture Toughness of Ceramics, Standard Reference Material Office, National Institute of Standards and Technology, Gaithersburg, MD, (1999).

[24] G. D. Quinn, K. Xu, R. Gettings, J. A. Salem, and J. J. Swab, SRM 2100: Fracture Toughness of Ceramics, pp. 499-530 in Fracture Mechanics of Ceramics, Vol. 14, R. C. Bradt, D. Munz, M. Sakai, and K. W. White, eds., Springer, USA (2005).

[25] G. D. Quinn, R. J. Gettings, and J. J. Kübler, Fracture Toughness of Ceramics by the Surface Crack in Flexure (SCF) Method, pp. 203-218 in Fracture Mechanics of Ceramics, Vol.11, R. C. Bradt, D. P. H. Hasselman, D. Munz, M. Sakai, and V. Yashevchenko, eds., (Plenum, NY) (1996).

[26] G. D. Quinn, Guide to Practice for Fractography of Ceramics and Glasses, NIST Special Publication SP 960-16, May 2007.

[27] J. C. Newman, Jr., and I. S. Raju, An Empirical Stress-Intensity Factor Equation for the Surface Crack, Eng. Fract. Mech. 15 [1-2], 185-92 (1981).

[28] J. B. Quinn, V. Sundar, and I. K Lloyd, Influence of microstructure and chemistry on the fracture toughness of dental ceramics, Dental Materials 19 (7), 603-11 (2003).

[29] J. Fischer, B. Stawarzcyk, A. Trottmann, and C. H. F. Hämmerle, Impact of thermal misfit on shear strength of veneering ceramic/zirconia composites, Dental Materials 25 [4], 419-423 (2009).

[30] M. V. Swain, Unstable cracking (chipping) of veneering porcelain on all-ceramic dental crowns and fixed partial dentures, Acta Biomater. 5, 1668-1677 (2009).
About the authors: Janet B. Quinn was a staff scientist in the Paffenbarger Research Center (PRC) of the American Dental Association Foundation (ADAF) until her untimely death in July 2008. George D. Quinn was a research ceramic engineer in the Ceramics Division of MSEL in NIST from 1990 to 2009. He is now a Research Associate for MSEL and a consultant to the PRC-ADAF. Veeraraghavan Sundar is Manager, Professional Service and Clinical Education, for Dentsply Prosthetics, York, PA. The National Institute of Standards and Technology is an agency of the U.S. Department of Commerce. 